\title{
Aplikasi asetaldehida melalui teknik perendaman terhadap karakteristik mutu teknis karet alam
}

\section{The acetaldehyde application through soaking technique towards the technical quality characteristics of natural rubber}

\author{
Afrizal Vachlepi \\ Balai Penelitian Sembawa - Pusat Penelitian Karet \\ Jl. Raya Palembang - Pangkalan Balai Km.29 Kotak Pos 1127 Palembang 30001 Indonesia \\ Penulis korespondensi. Telp: +627117439493, Fax.: +627117439282 \\ E-mail: a_vachlepi@yahoo.com
}

Diterima: 23 Maret 2019

Direvisi: 31 Oktober 2019

Disetujui: 6 Nopember 2019

\begin{abstract}
The raw material for the production of SIR 20 rubber comes from smallholders plantations thus tire factory has begun to substitute with a more efficient constant viscosity rubber. Production of constant viscosity rubber requires additives such as acetaldehyde. This study aimed to explore technical quality characteristics of natural rubber produced using rubber processing materials with various types of coagulant and soaking time in the acetaldehyde stabilizer using a factorial complete random design. The results showed that various types of coagulant and immersion time in acetaldehyde solution significantly affected the quality parameters of $P_{0}, P R I$, Mooney viscosity and ash content, but did not affect the SVI and volatile matter content. The quality of natural rubber produced from various treatments was fullfilled SIR 20 quality requirements based on SNI 06-1903-2000. Only natural rubber with liquid smoke coagulant that meets requirements for natural rubber CV-70 which has Mooney viscosity75-76.
\end{abstract}

Keywords : additives, natural rubber, quality, viscosity.

\begin{abstract}
ABSTRAK
Bahan baku untuk produksi karet SIR 20 sebagian besar berasal dari kebun petani sehingga pabrik ban mulai mensubstitusi dengan karet viskositas mantap yang lebih efisien. Produksi karet viskositas mantap memerlukan bahan aditif seperti asetaldehida. Tujuan penelitian ini adalah untuk mengetahui dan mempelajari karakteristik mutu teknis karet alam yang diproduksi menggunakan bahan olah karet (bokar) dengan berbagai jenis koagulan dan waktu perendaman dalam bahan pemantap asetaldehida menggunakan rancangan acak lengkap faktorial. Hasil penelitian menunjukkan bahwa perlakuan berbagai jenis koagulan dan waktu perendaman dalam larutan asetaldehida berpengaruh secara signifikan pada parameter mutu $\mathrm{P}_{0}$, PRI, viskositas Mooney dan kadar abu, tetapi tidak berpengaruh terhadap SVI dan kadar zat menguap. Mutu karet alam yang dihasilkan dari berbagai perlakuan sesuai dengan persyaratan mutu SIR 20 berdasarkan SNI 06-1903-2000. Hanya karet alam dengan koagulan asap cair yang memenuhi persyaratan mutu untuk karet alam CV-70 dimana viskositas Mooney karet alam tersebut sebesar 75-76.
\end{abstract}

Kata kunci : aditif, karet alam, mutu, viskositas.

\section{PENDAHULUAN}

Produk ekspor karet alam Indonesia masih didominasi karet remah yang dikenal dengan Standard Indonesian Rubber (SIR). Produk utama yang diproduksi berupa karet SIR 20. Karet jenis ini sebagian besar diproduksi menggunakan bahan olah karet (bokar) dari petani. Survei yang dilakukan oleh Syarifa et al. (2013) di Provinsi Sumatera Selatan mendapatkan bahwa mutu bokar petani masih belum baik karena sebagian petani masih mencampurkan kontaminan seperti tatal (kulit kayu sadapan) ke dalam bokar. Selain itu, masih banyak ditemukan petani yang menggunakan bahan penggumpal (koagulan) yang tidak direkomendasi oleh
Pusat Penelitian Karet seperti asam sulfat (Vachlepi et al., 2018). Rendahnya mutu bokar tersebut dapat menurunkan daya saing karet alam Indonesia di pasar internasional. Industri ban merupakan konsumen terbesar karet alam dunia. Pabrik ban saat ini cenderung menggunakan karet yang viskositasnya mantap atau tidak meningkat selama penyimpanan (Cifriadi et al., 2009), yaitu karet SIR $20 \mathrm{CV}$ (constant viscosity). Penggunaan karet jenis ini dapat mengurangi proses mastikasi pada saat pembuatan kompon karet. Energi yang dibutuhkan untuk proses ini sebesar 33-35\% dari total energi pada saat pembuatan kompon (Solichin \& Immanuel, 1991). Mastikasi merupakan proses pelunakan karet 
alam untuk mempermudah pencampuran dengan bahan kimia untuk karet (Cifriadi et al., 2009; Alam, 2008). Proses mastikasi ini mengkonsumsi energi yang cukup besar dan mungkin sangat mahal (Daik et al., 2007).

Perubahankebutuhanbahanbakukaretalam dipabrik ban menyebabkan meningkatnya permintaan ekspor karet viskositas mantap. Jumlah ekspor karet viskositas mantap dari Indonesia pada tahun 2009 yang hanya mencapai 59,8 ribu ton mengalami peningkatan menjadi 79,3 ribu ton pada tahun 2012 (Gapkindo, 2013). Karet viskositas mantap diproduksi sama seperti karet SIR 20. Salah satu upaya untuk menjaga kestabilan viskositas karet alam dilakukan dengan penambahan bahan aditif atau biasa disebut dengan bahan pemantap. Beberapa bahan yang dapat digunakan sebagai bahan pemantap antara lain HNS (Cifriadietal.,2009), hidrazinehidrat(Vachlepietal.,2014) dan asetaldehida (Solichin, 1995; Vachlepi et al., 2015).

Aplikasi bahan pemantap dapat dilakukan pada beberapa fase bahan olah karet (bokar) antara lain pada fase cair berupa lateks kebun dan pada fase padat seperti slab, blanket atau remahan karet alam. Teknis aplikasi bahan pemantap pun cukup beragam mulai dengan cara pencampuran ke dalam lateks pada fase cair, serta perendaman, penyemprotan dan penetesan pada blanket pada fase padat. Pemilihan teknis aplikasi ini sangat bergantung dari jenis bokar yang digunakan dan tahapan proses produksi karet alam. Aplikasi bahan pemantapuntuk pabrik karet remah yang mengolah bokar berupa slab (fase padat) umumnya dilakukan dengan cara penyemprotan baik pada blanket maupun remahan karet alam.

Pemilihan jenis bahan pemantap, teknis aplikasi dan jenis bokar yang digunakan sangat mempengaruhi mutu karet viskositas mantap yang dihasilkan. Penelitian aplikasi asetaldehida dalam pembuatan karet viskositas mantap dengan metode perendaman blanket (fase padat) masih sedikit dilakukan. Beberapa penelitian yang sudah dilakukan menunjukkan bahwa asetaldehida dapat digunakan untuk menghasilkan karet alam yang viskositasnyamantap(Solichin, 1995;Vachlepietal.,2015). Penelitian ini bertujuan untuk mengetahui dan mempelajari karakteristik mutu teknis karet alam yang diproduksi menggunakan bokar dengan berbagai jenis koagulan dan perendaman dalam bahan pemantap asetaldehida.

\section{BAHAN DAN METODE}

Penelitian ini dilakukan di Laboratorium Teknologi Pengolahan di Balai Penelitian Sembawa. Bahan yang digunakan adalah lateks kebun yang diperoleh dari kebun riset Balai Penelitian Sembawa, asam format atau asam semut teknis, asam sulfat atau cuka para teknis, asap cair merek Deorub, $\mathrm{P}_{2} \mathrm{O}_{5}$ dari Merck dan asetaldehida dari Sigma Alderich. Peralatan yang digunakan antara lain bak penggumpal, mesin creeper, gilingan terbuka (open mill), oven, rapid plastimeter, Mooney viskometer, neraca digital, stopwatch dan muffle furnace.

Rancangan yang digunakan pada penelitian ini adalah rancangan acak lengkap faktorial (RALF). Faktor perlakuan yang diberikan terdiri atas jenis koagulan yang digunakandanlamaperendamandalamlarutanasetaldehida. Jenis koagulan yang digunakan berupa asam format, asam sulfat dan asap cair. Perlakuan lama perendaman terdiri atas 0 menit atau tanpa perendaman (kontrol), 15 menit dan 30 menit. Parameter mutu teknis yang diamati terdiri atas plastisitas awal $\left(\mathrm{P}_{0}\right)$, indeks ketahanan plastisitas (plasticity retention indek/PRI), viskositas Mooney, indeks kestabilan viskositas (stability viscosity index/SVI), kadar zat menguap dan kadar abu. Hasil pengujian parameter mutu teknis karet yang dihasilkan juga dibandingkan dengan persyaratan mutu yang tercantum dalam Standar Nasional Indonesia (SNI) 06-1903-2000 tentang Standard Indonesian Rubber (SIR) seperti terlihat pada Tabel 1.

\section{Pembuatan Blanket Karet Menggunakan Berbagai Koagulan}

Bahan baku yang digunakan untuk pembuatan blanket karet alam adalah lateks kebun yang diperoleh dari kebun riset Balai Penelitian Sembawa. Lateks kebun yang digunakan sebanyak 60 liter untuk perlakuan jenis koagulan yang terdiri atas asam format, asam sulfat dan asap cair. Setiap koagulan digunakan untuk menggumpalkan lateks sekitar 20 liter menjadi koagulum (lateks yang sudah menggumpal). Selanjutnya koagulum digiling menggunakan mesin creeper menjadi blanket.

\section{Aplikasi Asetaldehida pada Blanket Karet Alam}

Aplikasi asetaldehida pada blanket karet alam dilakukan dengan teknik perendaman. Asetaldehida yang digunakan umumnya berupa larutan dengan konsentrasi 10\% (Solichin, 1995; Vachlepi et al., 2015). Sebelum aplikasi asetaldehida, blanket terlebih dahulu dibagi menjadi tiga bagian sesuai dengan perlakuan lama perendaman. Selanjutnya blanket karet direndam dalam asetaldehida $10 \%$ sesuai dengan lama perendaman. Semua blanket yang sudah direndam dalam asetaldehida kemudian dikeringkan dalam oven bersuhu sekitar $105{ }^{\circ} \mathrm{C}$ selama 3-4 jam. Blanket kering dianalisa mutu teknisnya sesuai dengan parameter pengamatan.

\section{HASIL DAN PEMBAHASAN}

\section{Plastisitas Karet Alam}

Plastisitas karet alam yang diamati terdiri atas plastisitas awal/ $\mathrm{P}_{0}$ (Gambar 1) dan indeks ketahanan plastisitas atau plasticity retention index (PRI) (Gambar 2). Nilai $\mathrm{P}_{0}$ dan PRI merupakan parameter dasar untuk menentukan mutu karet (Achmadi et al., 2015).

Berdasarkan Gambar 1 diketahui bahwa perlakuan jenis koagulan dan waktu perendaman karet alam dalam asetaldehida berpengaruh secara signifikan terhadap nilai plastisitas awal $\left(\mathrm{P}_{0}\right)$ karet alam. Nilai $\mathrm{P}_{0}$ tertinggi dihasilkan karet alam yang menggunakan asam format dengan waktu perendaman dalam asetaldehida selama 30 menit, yaitu 49 . Sedangkan nilai $\mathrm{P}_{0}$ terendah pada karet alam menggunakan asap cair dengan waktu perendaman 15 menit, yaitu 43.

Perbedaan hasil analisa nilai $\mathrm{P}_{0}$ ini lebih disebabkan oleh pembentukan mikrogel, yaitu ikatan di dalam individu partikel karet (intra particle crosslink). 
Tabel 1. Persyaratan mutu SNI 06-1903-2000 tentang Standard Indonesian Rubber (BSN, 2000).

\begin{tabular}{|c|c|c|}
\hline \multirow{2}{*}{ Spesifikasi / (asal bahan olah) } & SIR $3 \mathrm{CV}$ & SIR 20 \\
\hline & lateks & koagulum \\
\hline Kadar kotoran, $\%$ maks. (b/b) & 0,03 & 0,20 \\
\hline Kadar abu, \% maks. (b/b) & 0,50 & 1,00 \\
\hline Kadar zat menguap, \% maks. (b/b) & 0,80 & 0,80 \\
\hline PRI, min. & 60 & 50 \\
\hline $\mathrm{P}_{0}$, min. & - & 30 \\
\hline Nitrogen $(\mathrm{N})$, maks. (b/b) & 0,60 & 0,60 \\
\hline ASHT (Satuan Plastistas Wallace), maks. & 8 & - \\
\hline Viskositas Mooney Ml(1+4)100 & $*)$ & - \\
\hline $\begin{array}{l}\text { *)Tanda pengenal tingkatan } \\
\text { CV }-50 \\
\text { CV }-60 \\
\text { CV }-70\end{array}$ & & \\
\hline
\end{tabular}

Mikrogel tersebut akan terjadi ikatan silang lebih lanjut yang disebut makrogel. Nilai $\mathrm{P}_{0}$ karet alam sebagian dipengaruhi oleh pembentukan mikrogel dan makrogel (Solichin \& Setiadi, 1992). Kondisi ini sesuai dengan penelitian Solichin (1995) dimana nilai $\mathrm{P}_{0}$ karet alam akan cenderung menurun selama pengolahan. Hal ini diduga terjadi karena kandungan air yang terdapat pada larutan asetaldehida $10 \%$. Adanya air dalam bahan pemantap dapat menyebabkan pertumbuhan mikroorganisme yang merusak protein pada molekul karet alam. Pertumbuhan mikroorganisme yang merusak protein tersebut dapat menyebabkan nilai $\mathrm{P}_{0}$ rendah (Solichin \& Anwar, 2003).

Walaupun demikian, hasil analisa parameter mutu $\mathrm{P}_{0}$ semua perlakuan memenuhi persyaratan mutu jenis karet SIR 20 sesuai SNI 06-1903-2000 dimana syarat minimal nilai $\mathrm{P}_{0}$ karet alam adalah 30 (Tabel 1). Hasil analisa ini membuktikan bahwa penggunaan bahan pemantap asetaldehida pada fase padat(blanket) tidak mempengaruhi plastisitas awal karet alam. Pengujian PRI merupakan cara yang sederhana dan cepat untuk mengetahui ketahanan karet mentah terhadap degradasi oleh oksidasi pada suhu tinggi. Faktor utama yang mempengaruhi nilai PRI adalah pertimbangan antara prooksidan dan antioksidan dalam karet (Solichin, 1991). Semakin tinggi nilai PRI, maka semakin baik mutu karet (Montha et al., 2016).
Seperti terlihat pada Gambar 2 diketahui bahwa penggunaan asetaldehida berpengaruh secara signifikan terhadap nilai PRI karet alam. Nilai PRI karet alam dengan bahan aditif asetaldehida secara umum lebih tinggi dibandingkan perlakuan tanpa perendaman (kontrol), kecuali karet yang digumpalkan dengan asam format dan direndam dalam asetaldehida selama 30 menit. Nilai PRI yang tinggi dari karet alam dengan perendaman asetaldehida menunjukkan bahwa asetaldehida mampu menghasilkan karet alam yang tahan terhadap suhu tinggi (Solichin, 1991) dan tahan terhadap proses ozonolisis (oksida oleh ozon) (Aguele et al., 2015).

Nilai PRI karet alam yang direndam dalam asetaldehida berkisar 71,6-82,2. Karet alam kontrol (tanpa perendaman) mempunyai nilai PRI sekitar 75,678,3. Hasil pengujian PRI ini memenuhi persyaratan mutu untuk jenis karet SIR 20 sesuai dengan SNI 06-1903-2000 tentang SIR seperti terlihat pada Tabel 1. Persyaratan nilai PRI karet ekspor jenis mutu SIR 20 minimal 50. Nilai PRI karet alam semua perlakuan relatif tidak konstan. Adanya fluktuasi perubahan nilai PRI, walaupun perbedaannya kecil seperti pada blanket asam format (Gambar 2), diduga lebih disebabkan oleh kondisi lingkungan. Hal ini sesuai dengan penelitian Intapun et al. (2009) yang menyatakan bahwa kondisi lingkungan (suhu, $\mathrm{pH}$ dan oksigen

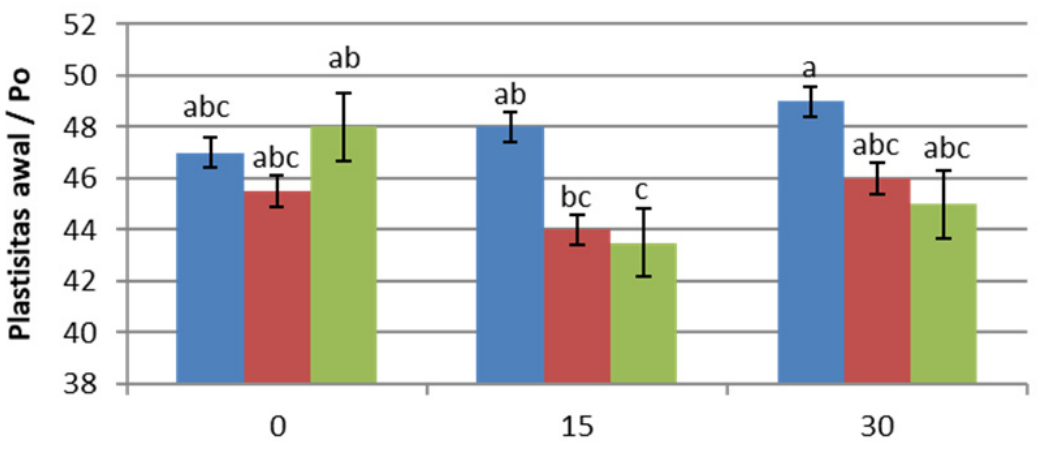

Waktu perendaman dalam asetaldehida (menit)

- Asam Format $\quad$ Asam Sulfat $=$ Asap Cair

Keterangan : angka-angka yang diikuti huruf yang sama pada grafik batang berarti tidak berbeda pada uji lanjutan Jarak Berganda Duncan (DMRT) pada tingkat kepercayaan $95 \%(\dot{\alpha}=0,05)$

Gambar 1. Nilai plastisitas awal $\left(\mathrm{P}_{0}\right)$ karet alam menggunakan bahan pemantap asetaldehid. 
dalam udara) selama penyimpanan akan mempengaruhi sensibilitas karet alam terhadap oksidasi suhu tinggi.

\section{Viskositas dan Kestabilannya}

Parameter mutu viskositas yang diamati pada penelitian ini berupa viskositas Mooney dan indeks kestabilan viskositas (stability viscosity index/SVI). Parameter viskositas Mooney menggambarkan panjang rantaimolekulkaret. Parametermutu inimemegangperanan penting dalam proses pencampuran ketika pembuatan kompon, baik untuk tingkat dispersi bahan-bahan kimia kompon di dalam karet maupun energi yang diperlukan untuk penggilingan di mesin pencampur. Viskositas yang terlalu tinggi menyebabkan tingginya konsumsi daya mesin pemroses. Sebaliknya jika viskositasnya sangat rendah, menyebabkan rendahnya gaya geser pada pencampuran yang berakibat material cenderung beraglomerasi sehingga homogenitasnya rendah (Maspanger, 2008).

Viskositas Mooney biasanya digunakan juga sebagai indikator teknologi untuk mengetahui karakterisasi partikel karet ditinjau dari kemampuannya saat pemrosesan lebih lanjut, termasuk pada saat pembuatan kompon (Zheleva, 2013). Berbeda dengan viskositas, parameter SVI lebih menggambarkan perubahan nilai viskositas Mooney karet alam selama penyimpanan sebelum karet alam diproses lebih lanjut menjadi barang jadi karet. Nilai SVI ini menunjukkan seberapa stabil viskositas karet alam selama penyimpanan. Hasil analisa parameter mutu viskositas Mooney dan SVI ditampilkan pada Gambar 3 dan Tabel 2.

Seperti terlihat pada Gambar 3 diketahui bahwa hasil analisa statistik menunjukkan bahwa perlakuan waktu perendaman dalam asetaldehida tidak berpengaruh nyata terhadap nilai viskositas Mooney karet alam. Kondisi ini diduga terjadi karena dengan perendaman dalam larutan konsentrasi 10\%, kemampuan asetaldehida belum maksimal dalam mencegah pembentukan ikatan silang pada partikel karet alam. Hasil ini ditunjukkan dari adanya kecenderungan kenaikan nilai viskositas Mooney. Fenomena ini menunjukkan bahwa aplikasi asetaldehida dengan metode perendaman (soaking) belum efektif dalam menurunkan nilai viskositas Mooney karet alam.

Nilai viskositas Mooney karet alam ternyata lebih dipengaruhi oleh perlakuan jenis koagulan (Gambar 3). Viskositas Mooney karet alam dengan bahan penggumpal kelompok asam (asam format dan asam sulfat) yaitu sekitar 81-91. Tingginya viskositas Mooney karet alam yang digumpalkan dengan koagulan kelompok asam disebabkan terjadinya ikatan silang antar molekul karet alam yang terjadi secara alami dan ditandai dengan kenaikan nilai viskositas Mooney (Solichin, 1995).

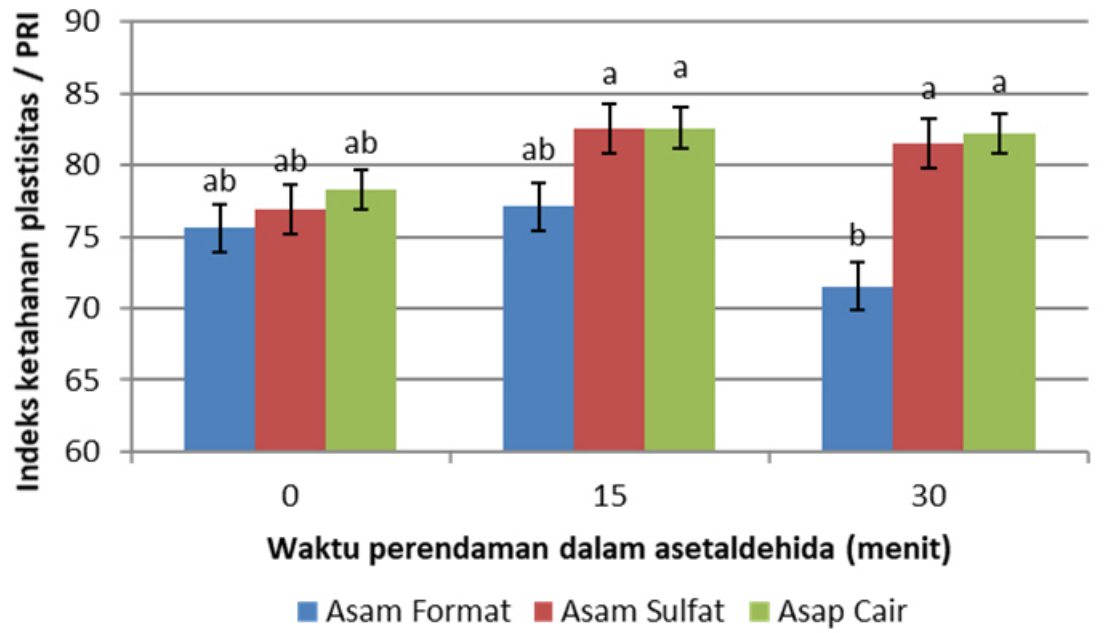

Ket : angka-angka yang diikuti huruf yang sama pada grafik batang berarti tidak berbeda pada uji lanjutan Jarak Berganda Duncan (DMRT) pada tingkat kepercayaan $95 \%(\dot{\alpha}=0,05)$

Gambar 2. Indeks ketahanan plastisitas (PRI) karet alam berbagai perlakuan.

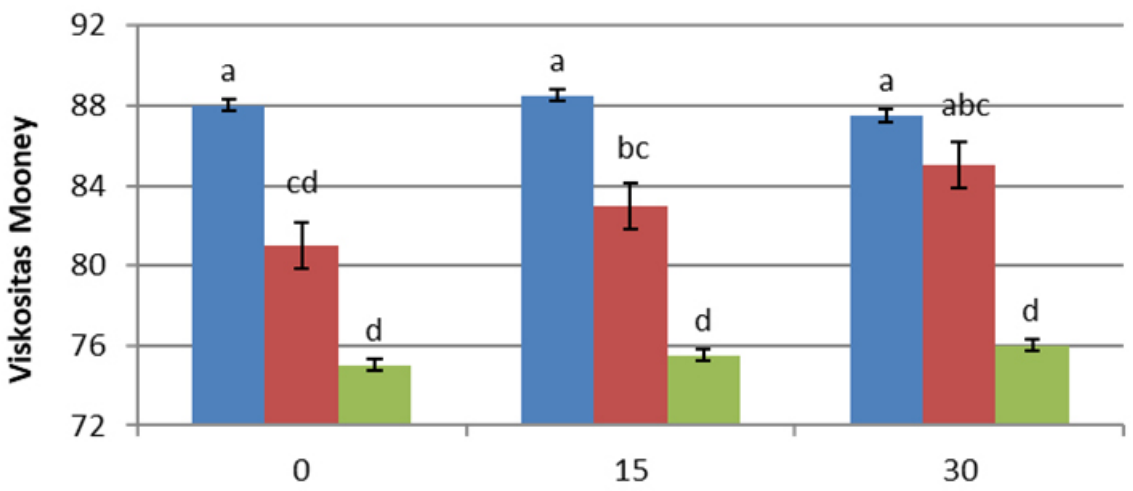

Waktu perendaman dalam asetaldehida (menit)

- Asam Format Asam Sulfat Asap Cair

Ket : angka-angka yang diikuti huruf yang sama pada grafik batang berarti tidak berbeda pada uji lanjutan Jarak Berganda Duncan (DMRT) pada tingkat kepercayaan $95 \%(\dot{\alpha}=0,05)$

Gambar 3. Viskositas Mooney karet alam dengan berbagai perlakuan. 
Fenomena ini membuktikan bahwa koagulan kelompok asam, baik asam format maupun asam sulfat, tidak mampu mencegah reaksi ikatan silang pada karet alam.

Karet alam yang digumpalkan dengan asap cair mempunyai Viskositas Mooney lebih rendah (7576) dibandingkan asam format dan asam sulfat. Nilai viskositas Mooney yang rendah tersebut menunjukkan bahwa asap cair mampu mencegah karet alam dari pengerasan selama proses pengolahan sehingga karet alam tetap lunak yang disebabkan senyawa kimia yang ada di asap cair. Solichin et al. (2005) menyatakan bahwa asap cair mengandung sekitar 67 jenis senyawa yang dapat berfungsi sebagai antibakteri (Karseno et al., 2002), antioksidan, pemberi warna coklat dan bau asap yang khas.

Seperti terlihat pada Tabel 2 diketahui bahwa perlakuan jenis koagulan dan waktu perendaman dalam asetaldehida tidak berpengaruh secara signifikan terhadap indeks kestabilan viskositas (SVI) karet alam. Hasil analisa ini menunjukkan bahwa aplikasi asetaldehida menggunakan metode perendaman (soaking) belum efektif dalam mencegah terjadi ikatan silang pada partikel karet alam yang ditandai tingginya nilai SVI.

Nilai SVI semua perlakuan berkisar antara 3-6. Angka ini menggambarkan bahwa selama penyimpanan dan pengangkutan, viskositas karet alam dapat mengalami perubahan sekitar 3-6 dari nilai awal viskositas Mooney setelah pengolahan. Semakin kecil nilai SVI maka semakin stabil (konstan) viskositas Mooney karet alam. Karet alam dengan nilai viskositas Mooney yang tetap rendah (nilai SVI juga rendah) dapat mempersingkat proses mastikasi sehingga lebih efisien dalam penggunaan energi. Energi yang dibutuhkan untuk proses mastikasi ini sebesar 33-35\% dari total energi pada saat pembuatan kompon karet (Solichin \& Immanuel, 1991).

Berdasarkan analisa parameter mutu ini aplikasi asetaldehida melalui teknik perendaman masih kurang efektif. Dari semua perlakuan, hanya karet alam yang digumpalkan dengan koagulan asap cair yang mempunyai nilai viskositas Mooney memenuhi standar mutu CV-70 (Tabel 1). Persyaratan mutu karet CV-70 harus mempunyai viskositas Mooney sekitar 65-75.

\section{Kadar Abu}

Kadar abu merupakan salah satu parameter mutu yang dipersyaratkan dalam SNI 06-1903-2000 tentang SIR. Karet alam yang boleh diekspor untuk mutu SIR 20 adalah maksimum 1\% (Tabel 1). Hasil analisa kadar abu dengan berbagai perlakuan semuanya memenuhi persyaratan SNI dengan kadar abu sekitar 0,21-0,58\%.

Berdasarkan analisa statistik seperti terlihat pada Gambar 4 diketahui bahwa kadar abu karet alam yang dihasilkan secara signifikan tidak dipengaruhi oleh perlakuan perendaman dalam asetaldehida. Hal ini disebabkan asetaldehida bukan termasuk dalam senyawa anorganik yang akan dianalisa sebagai abu dalam karet alam. Kadar abu merupakan persentase kandungan senyawa atau ion anorganik dalam karet alam. Hasil ini membuktikan bahwa penggunaan asetaldehida dalam pengolahan karet alam tidak akan meningkatkan kadar abu.

Penggunaan berbagai koagulan pada karet alam secara signifikan lebih berpengaruh terhadap kadar abu (Gambar 4). Karet alam yang digumpalkan dengan koagulan asam sulfat cenderung mempunyai kadar abu yang lebih tinggi dibandingkan koagulan asam format dan asap cair. Hasil ini sesuai dengan kajian Purbaya dan Suwardin (2015). Tingginya kadar abu pada karet alam tersebut disebabkan adanya kandungan sulfur (belerang) yang berbentuk senyawa sulfat anorganik. Kadar abu karet alam yang digumpalkan dengan asam sulfat berkisar antara $0,54-0,58 \%$. Sementara koagulan asam format dan asap cair termasuk dalam golongan senyawa organik yang tidak terhitung sebagai kadar abu sehingga hanya mempunyai kadar abu sekitar 0,21-0,42\%. Walaupun berbeda nyata, hasil analisa kadar abu dari karet alam berbagai perlakuan memenuhi semua persyaratan mutu SNI 06-1903-2000 tentang SIR (Tabel 1) untuk karet SIR 20.

\section{Kadar Zat Menguap}

Dalam SNI 06-1903-2000 tentang SIR, salah satu persyaratan mutu yang harus dipenuhi agar karet alam dapat diekspor ke berbagai negara tujuan adalah kadar zat menguap. Persyaratan maksimal kadar zat menguap dalam karet alam yaitu $0,80 \% \mathrm{~b} / \mathrm{b}$.

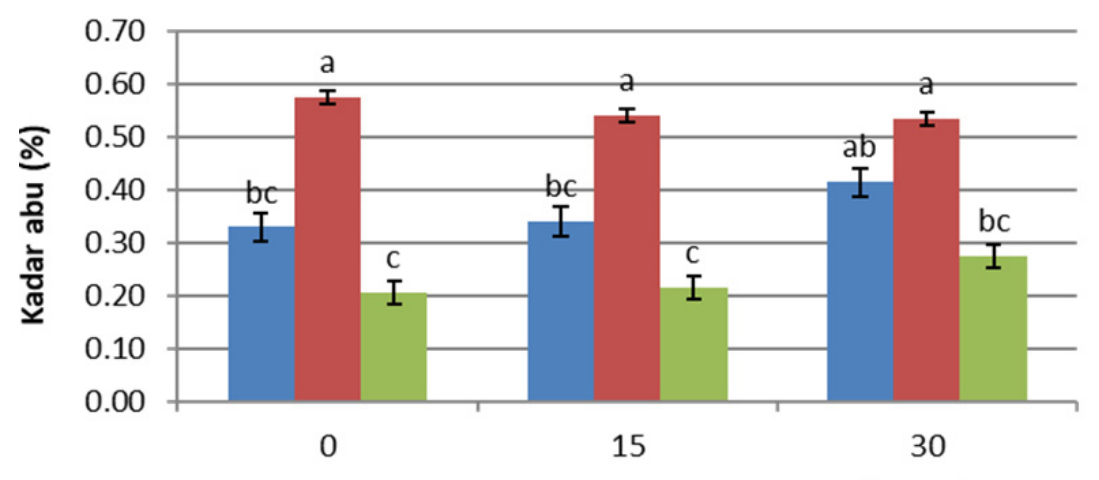

Waktu perendaman dalam asetaldehida (menit)

- Asam Format asam Sulfat $=$ Asap Cair

Ket : angka-angka yang diikuti huruf yang sama pada grafik batang berarti tidak berbeda pada uji lanjutan Jarak Berganda Duncan (DMRT) pada tingkat kepercayaan $95 \%(\alpha ́=0,05)$

Gambar 4. Kadar abu karet alam dengan berbagai perlakuan bahan penggumpal dan waktu perendaman aditif asetaldehida. 
Tabel 2. Indeks kestabilan viskositas (SVI) karet alam berbagai perlakuan.

\begin{tabular}{ccccc}
\hline \multirow{2}{*}{ Jenis koagulan } & \multicolumn{3}{c}{ Waktu perendaman (menit) } & \multirow{2}{*}{ Rerata (jenis koagulan) } \\
\cline { 2 - 4 } & 0 & 15 & 30 & $5,3 \mathrm{a}$ \\
Asam Format & 4,5 & 5,5 & 6,0 & $4,2 \mathrm{a}$ \\
Asam Sulfat & 5,5 & 4,0 & 3,0 & $6,0 \mathrm{a}$ \\
Asap Cair & 5,5 & 6,0 & 6,5 & \\
\hline
\end{tabular}

Rerata (waktu perendaman)

$5,2 \mathrm{a}$

5,2 a

5,2 a

Ket : angka-angka yang diikuti huruf yang sama pada baris dan kolom yang sama berarti tidak berbeda pada uji lanjutan Jarak

Berganda Duncan (DMRT) pada tingkat kepercayaan 95\% $(\dot{\alpha}=0,05)$

Tabel 3. Hasil analisa kadar zat menguap karet alam dengan berbagai perlakuan.

\begin{tabular}{ccccc}
\hline \multirow{2}{*}{ Jenis Koagulan } & \multicolumn{3}{c}{ Waktu Perendaman (menit) } & \multirow{2}{*}{ Rerata (jenis koagulan) } \\
\cline { 2 - 4 } & 0 & 15 & 30 & $0,53 \mathrm{a}$ \\
Asam Format & 0,60 & 0,47 & 0,51 & $0,48 \mathrm{a}$ \\
Asam Sulfat & 0,58 & 0,39 & 0,48 & $0,48 \mathrm{a}$ \\
Asap Cair & 0,46 & 0,49 & 0,51 &
\end{tabular}

Ket : angka-angka yang diikuti huruf yang sama pada baris dan kolom yang sama berarti tidak berbeda pada uji lanjutan Jarak Berganda Duncan (DMRT) pada tingkat kepercayaan $95 \%(\dot{\alpha}=0,05)$

Hasil analisa kadar zat menguap karet alam dengan berbagai perlakuan tidak dipengaruhi jenis koagulan dan waktu perendaman (Tabel 3). Kadar zat menguap karet alam semua perlakuan berkisar antara $0,39 \%-0,58 \%$ b/b. Angka ini menunjukkan bahwa semua karet alam yang dihasilkan memenuhi persyaratan mutu ekspor karena kadar zat menguapnya masih dibawah batas maksimal yang dipersyaratan.

\section{KESIMPULAN}

Perlakuan berbagai jenis koagulan dan waktu perendaman dalam larutan asetaldehida berpengaruh secara signifikan pada parameter mutu $\mathrm{P}_{0}$, PRI, viskositas Mooney dan kadar abu, tetapi tidak berpengaruh terhadap nilai SVI dan kadar zat menguap. Karet alam semua perlakuan memenuhi persyaratan mutu SNI 06-19032000 sebagai karet alam SIR 20. Hanya karet alam dengan koagulan asap cair yang memenuhi persyaratan mutu untuk karet alam CV-70 dimana viskositas Mooney karet alam tersebut sebesar 75-76. Penelitian lebih lanjut diperlukan untuk mendapatkan metode terbaik dalam aplikasi asetaldehida apabila menggunakan bahan olah karet dari petani dengan koagulan asam format dan asam sulfat.

\section{UCAPAN TERIMA KASIH}

Pada kesempatan ini penulis ingin menyampaikan terima kasih kepada Bapak Dr. Sinung Hendratno sebagai Kepala Balai Penelitian Sembawa-Pusat Penelitian Karet atas izin dan dukungan yang diberikan sehingga penelitian ini dapat dilaksanakan melalui kegiatan rutin in house Balai Penelitian Sembawa.

\section{DAFTAR PUSTAKA}

Achmadi, S.S., Cifriadi, A., \& Hidayah, M.N. (2015). Redistilat asap cair dari cangkang kelapa sawit dan aplikasinya sebagai koagulan karet alam. Jurnal Penelitian Karet, 33(2), 183-192.

Aguele, F., Idiaghe, J., \& Apugo-Nwosu, T. (2015). A study of quality improvement of natural rubber products by drying methods. Journal of Materials Science and
Chemical Engineering, 3, 7-12.http:// doi.org/10.4236/ msce.2015.311002

Alam, A. (2008). Mastikasi dan dasar proses pencampuran. Dalam Makalah Kursus Teknologi Barang Jadi Karet. Bogor: Balai Penelitian Teknologi Karet, 61-62.

Badan Standardisasi Nasional. (2000). Standar Nasional Indonesia (SNI) 06-1903-2000 tentang Standard Indonesia Rubber (SIR). 1-2.

Cifriadi, A., Fathurrohman, M.I., Syamsu, Y., Tedjaputra, N., \& Budianto, E. (2009). Proses pembuatan karet viskositas mantap jenis SIR $20 \mathrm{CV}$ pada fase padat. Jurnal Penelitian Karet, 27(2), 77-88.

Daik, R., Bidol, S., \& Abdullah, I. (2007). Effect of molecular weight on the droplet size and rheological properties of liquid natural rubber emulsion. Malaysian Polymer Journal, 2(1), 29-38.

Gapkindo. (2013). Buletin karet. Gabungan Perusahaan Karet Indonesia. ISSN 0216-9908, 3, th XXXV.

Intapun, J., Sainte-Beuve, J., Bonfils, F., Tanrattanakul, V., Dubreucq, E., \& Vaysse, L. (2009.) Characterisation of natural rubber cup coagula maturation conditions and consequences on dry rubber properties. Journal of Rubber Research, 12(4), 171-184.

Karseno, Darmadji, P., \& Rahayu, K. (2001). Daya hambat asap cair kayu karet terhadap bakteri pengkontaminan lateks dan ribbed smoke sheet. Agritech, 21(1), 10-15.

Maspanger, D. (2008). Sifat fisik karet. Dalam Makalah Kursus Teknologi Barang Jadi Karet. Bogor : Balai Penelitian Teknologi Karet, pp. 75-76.

Montha, S., Suwandittakul, P., Poonsrisawat, A., Oungeun, P., \& Kongkaew, C. (2016). Maillard reaction in natural rubber latex: Characterization and physical properties of solid natural rubber. Advances in Materials Science and Engineering, 1-6. http://doi. org/10.1155/2016/7807524

Suwardin, D., \& Purbaya, M. (2015). Jenis bahan penggumpal dan pengaruhnya terhadap parameter mutu karet spesifikasi teknis. Warta Perkaretan, 34(2), 147-160. https://doi.org/10.22302/ppk.wp.v34i2.256

Solichin, M., \& Immanuel, V. (1991). Kajian pembuatan sit angin yang viskositasnya dimantapkan. Buletin Perkaretan, 7(2), 94-100.

Solichin, M., \& Setiadi, T. (1992). Pengaruh penambahan 
hidroksilamin netral sulfat dan lama pemeraman terhadap mutu lum mangkok. Buletin Perkaretan, 8(1), $17-25$.

Solichin, M. (1991). Faktor-faktor yang mempengaruhi viskositas Mooney dalam pengolahan SIR $3 \mathrm{CV}$. Majalah Lateks, 6(2), 69-75.

Solichin, M. (1995). Pemantapan viskositas Mooney karet alam dengan natrium fenolat, natrium metabisulfit dan asetaldehida. Tesis Magister Universitas Gadjah Mada.

Solichin, M., \& Anwar, A. (2003). Pengaruh penggumpalan lateks, perendaman dan penyemprotan bokar dengan asap cair terhadap bau bokar, sifat teknis, dan sifat fisik vulkanisat. Jurnal Penelitian Karet, 21(1-3), 45-61.

Solichin, M., Pramuaji, I., \& Anwar, A. (2005). Deorub K sebagai pembeku dan pencegah timbulnya bau busuk karet. Workshop Bahan Pembeku Asap Cair yang Ramah Lingkungan. Palembang, tanggal 31 Mei 2005.

Syarifa, L. F., Agustina, D.S., \& Nancy, C. (2013). Evaluasi pengolahan dan mutu bahan olah karet rakyat (bokar) di tingkat petani karet di Sumatera Selatan. Jurnal Penelitian Karet, 31(2), 139-148.

Vachlepi, A., Suwardin, D., \& Hanifarianty, S. (2015). Penggunaan asetaldehid sebagai aditif dalam proses produksi karet spesifikasi teknis CV/LoV. Prosiding Diseminasi Hasil Litbang Industri. Palembang : Baristand Industri Palembang, 80-89.

Vachlepi, A., Suwardin, D., Purbaya, M., \& Hanifarianty, S. (2014). Application of hydrazine compound to produce constant viscosity rubber. Majalah Polimer Indonesia, 17(1), 1-5.

Vachlepi, A., Purbaya, M., Hanifarianty, S., \& Suwardin, D. (2018). Teknologi Pengolahan Bokar. Saptabina Usahatani Karet Rakyat. Balai Penelitian Sembawa Edisi ke-8. ISBN 979-529-002-9, pp 107-110.

Zheleva, D. (2013). An attempt for correlation between Mooney viscosity and rheological properties of filled rubber compounds. Journal of Chemical Technology and Metallurgy, 48(3), 241-246. 
